\title{
Follicular-patterned thyroid lesions
}

\section{Foliküler patern yapan tiroid lezyonları}

\author{
F. Fulya KÖYBAŞIOĞLU1, Özgür İlhan ÇELİK¹, Nuray Güneri TOSUNOĞLU², Binnur ÖNAL1, \\ Ayşegül ADABAĞ 1
}

TC SB Ankara Dışkapı YB Ĕğitim ve Araştırma Hastanesi, 1. Patoloji Bölümü Sitopatoloji Ünitesi ${ }^{1}$, Gazi Üniversitesi, Ticaret ve Turizm Eğitim Fakültesi Bilgisayar Uygulamaları Ĕ̈itimi ${ }^{2}$, ANKARA

\section{ABSTRACT}

Aim: Our aim is to determine the minimal cytopathologic criteria needed to make differential diagnosis in follicular-patterned lesions of the thyroid gland.

Materials and Methods: We reviewed 56 fine needle aspiration cytology specimens which were reported as "suspicious for follicular-patterned lesions of thyroid" between years 2001 and 2005 in our hospital and their histological slides. Parameters for cytopathologic assesment are cellularity, colloid formation, multilayered rosette formation, follicular cell rings, monolayered sheets, intact follicles, hyperplastic papillae, hyaline stromal fragments, intranuclear inclusions, nuclear grooves, angulated nuclei, nucleoli, cerebriform nuclei, nuclear size, macrophages, flame cells and Hurthle cells. Statistical analysis was performed using $\chi^{2}$ and Fisher's-exact tests and Kolmogorov-Simirnov test.

Results: Four cytopathologic features-cerebriform nuclei, angulated nuclei, nuclear grooves and intranuclear inclusion- were constantly observed in the follicular variant of papillary carcinoma $(p<0.05)$. Diluted colloid, monolayered sheet, nuclear size, macrophage and nucleoli were frequently seen in nodular hyperplasia $(p<0.05)$. The nuclear size was the sole differential cytopathologic criteria between follicular adenoma and follicular carcinoma $(p<0.05)$.

Conclusion: Detailed cytopathologic examination was found to be important in differentiating follicular variant of papillary carcinoma from nodular hyperplasia. On the other hand, none of the cytopathologic findings were sufficient to distinguish follicular adenoma from follicular carcinoma. Therefore, cytopathologists should report such lesions as "follicular neoplasms".

Key words: Follicular lesion, thyroid, cytopathologic criteria, cerebriform nucleus, fine needle aspiration cytology
ÖZET

Amaç: Çalışmanın amacı tiroidin folliküler patern yapan lezyonlarının ayırıcı tanısındaki minimal sitopatolojik kriterleri saptamaktır.

Gereç ve Yöntem: Hastanemiz sitopatoloji ünitesinde 2001 ve 2005 yılları arasında "folliküler patern yapan tiroid lezyonu şüphesi" tanısı alan 56 ince iğne aspirasyon sitolojisi materyali değerlendirmeye alındı. Sitopatolojik değerlendirmede kullanılan parametreler: hücresellik, kolloid yapısı, çok sıralı rozet yapısı, folliküler hücre dizilimleri, tek sıralı tabakalar, intakt folliküller, hiperplastik papilla, hyalin stromal fragmanlar, intranükleer inklüzyonlar, nükleer yarıklar, angüle nükleus, nükleol, serebriform nükleus, nükleer boyut, makrofajlar, flame hücreler ve Hürthle hücreleri idi. İstatistik analiz $\chi^{2}$ and Fisher-Exact Tests ve Kolmogorov-Simirnov Test kullanılarak yapıldı.

Bulgular: Papiller karsinom foliküler alt tipinde dört sitopatolojik özellik- serebriform nükleus, angule nükleus, nükleer yarık ve intranükleer inklüzyon- saptanmıştır $(p<0.05)$. Dilüe kolloid, tek sıralı tabaka, nükleer boyut, makrofaj ve nükleol sıklıkla nodüler hiperplazide görüldü $(p<0.05)$. Nükleer boyut foliküler adenom ve foliküler karsinom arasındaki tek sitopatolojik kriterdi $(p<0.05)$.

Sonuç: Ayrıntılı sitopatolojik değerlendirme, papiller karsinom foliküler alt tipini nodüler hiperplaziden ayırt etmede önemli bulunmuştur. Diğger tarafta, sitopatolojik bulguların hiçbiri foliküler adenomu foliküler karsinomdan ayırt etmede yeterli değildir. Bunun için sitopatolog bu gibi lezyonları "foliküler neoplazi" olarak rapor etmelidir.

Anahtar sözcükler: Foliküler lezyon, tiroid, sitopatolojik kriter, serebriform nükleus, ince iğne aspirasyon sitolojisi

\section{INTRODUCTION}

Fine needle aspiration cytology (FNAC) of thyroid nodules has been proved to be reliab- 
le primary diagnostic tool in the diagnosis of thyroid nodules $(1,2,3)$. However, follicular neoplasms are at grey zone (4). Differentiation among various follicular-patterned lesions of the thyroid including nodular hyperplasia, follicular variant of papillary carcinoma, follicular adenoma, and follicular carcinoma, is the main area of diagnostic difficulty $(4,5,6)$. The purpose of this study was to determine the minimal cytological criteria needed to make differential diagnosis in follicular-patterned lesions of the thyroid gland.

\section{MATERIALS AND METHODS}

The cytological samples for this study were obtained by a retrospective computerized search of all our thyroid FNAC reports. A total of 4080 thyroid FNAC were performed in the Cytology Unit and Radiology Department of our hospital between April 2001 and December 2005. Among them, cytology was benign in $2711(66.45 \%)$, malignant in $46(1.13 \%)$ and nondiagnostic in $1098(26.91 \%)$ patients. These groups were excluded from our study. Two hundred twenty five $(5.51 \%)$ specimens were evaluated as suspicious cytology (diagnosis) for follicular-patterned lesions of the thyroid (descriptive diagnosis). Histopathological follow-up was available for $56(24.8 \%)$ cases which were operated in our hospital which also constituted the study group. Histopathological diagnoses of these 56 cases were nodular hyperplasia $(\mathrm{NH})$ $(n=29,51.8 \%)$, follicular adenoma (FA) $(n=13$, $23.2 \%$ ), follicular variant of papillary carcinoma $(\mathrm{FVPC})(\mathrm{n}=9,16.1 \%)$ and follicular carcinoma (FC) $(n=5,8.8 \%)$.

Thyroid fine needle aspirations were performed by (cyto)pathologists and radiologists using 22-27 gauge needles attached to 10 $\mathrm{ml}$ plastic syringes. (Cyto)pathologists used Cameco syringe holders (Cameco, Sweden) in order to fix the syringe, and prepared both airdried and wet-fixed (95\% ethanol) smears Radiologists smeared the aspirated materials directly on clean glass slides and let them airdry. The air-dried smears were stained with May -Grünwald Giemsa (MGG) and the alcoholfixed smears with Papanicolaou (PAP) and Hematoxylene-Eosin (HE) solutions.

The parameters for cytological assessment included cellularity, the presence of colloid, multilayered rosettes (a form of ring lined by stratified follicular cells), follicular cell rings (small follicular groups of follicular cells from 6 to 12 are arranged as a ring with or without a small amount of central colloid ), monolayered sheets, intact follicles (consisted of spheres of colloid surrounded by nuclei imparting a threedimensional appearance), hyperplastic papillae (Hp) (papillary cellular structures containing intact- nonintact follicles), hyaline stromal fragments, intranuclear inclusions (INI), nuclear groove (NG), angulated nuclei, nucleoli, cerebriform nuclei, nuclear size, macrophages, flame cells and Hurthle cells (Figure 1,2,3,4).

The presence of these cytomorphological features was scored ranging from 0 to 2 . [(for colloid: 0, none; 1, watery; 2, globularropy) (for the nuclear size-comparison to a red blood cell- $1,<\mathrm{x}^{2} ; 2,>\mathrm{x}^{2}$ ) (for the other cytomorphological features: 0 , absent; 1(mild), $<50 \%$ of that case; 2 (High), $>50 \%$ of that case)]. Hypocellular slides were excluded in this study, as they were 'nondiagnostic'. Other available data such as patients' age, gender and nodule size were also considered.

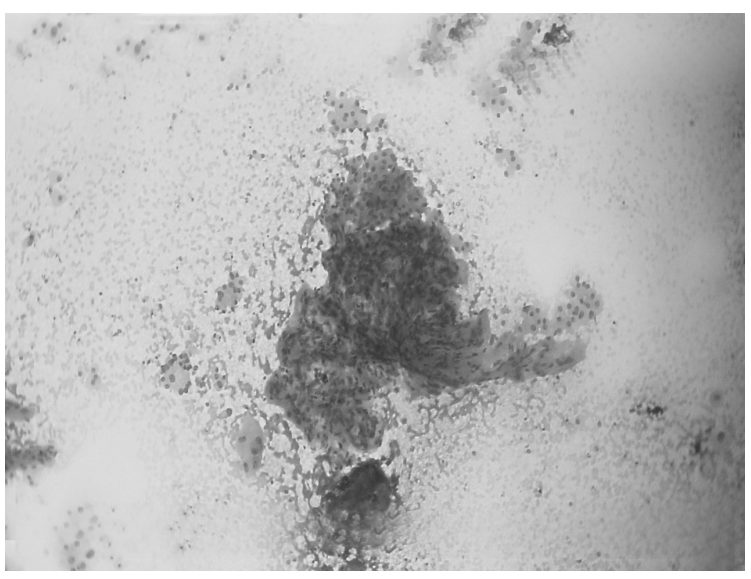

Figure 1. Hyaline stromal fragment attached to epithelial cells (May Grünwald Giemsa x100). 


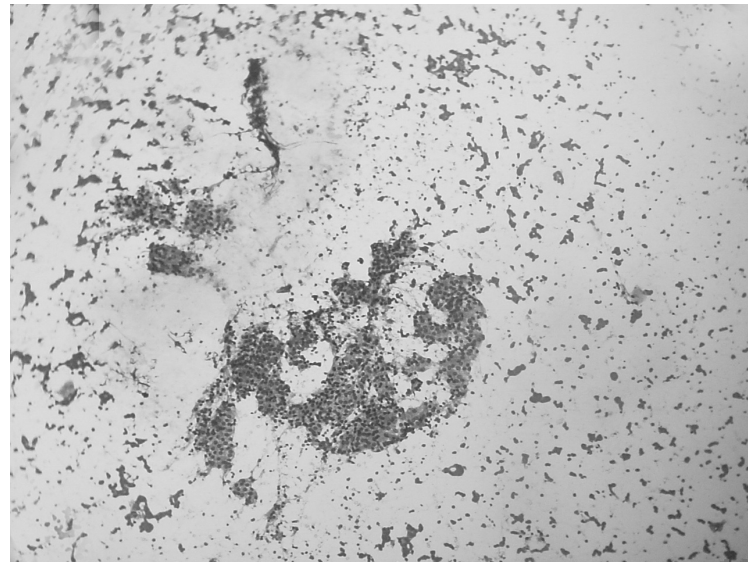

Figure 2. Hyperplastic papilla (May Grünwald Giemsa x100).

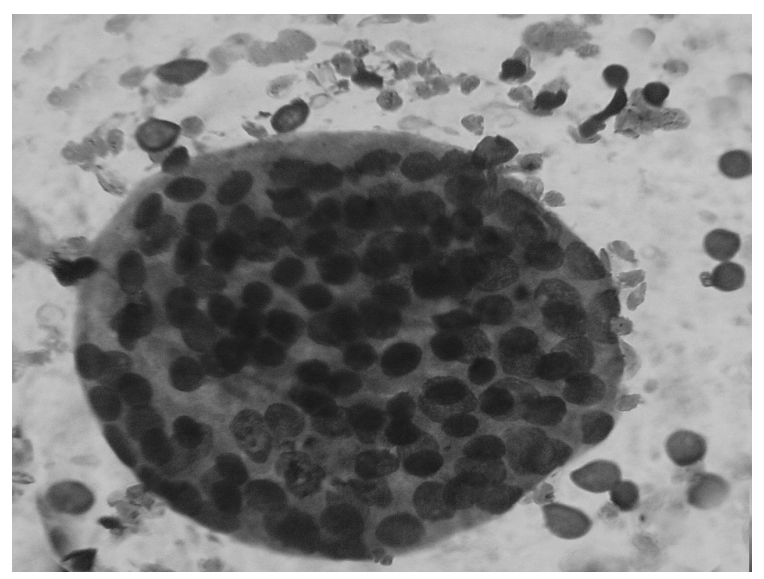

Figure 3. Intact follicle (May Grünwald Giemsa x100/1.25,oil).

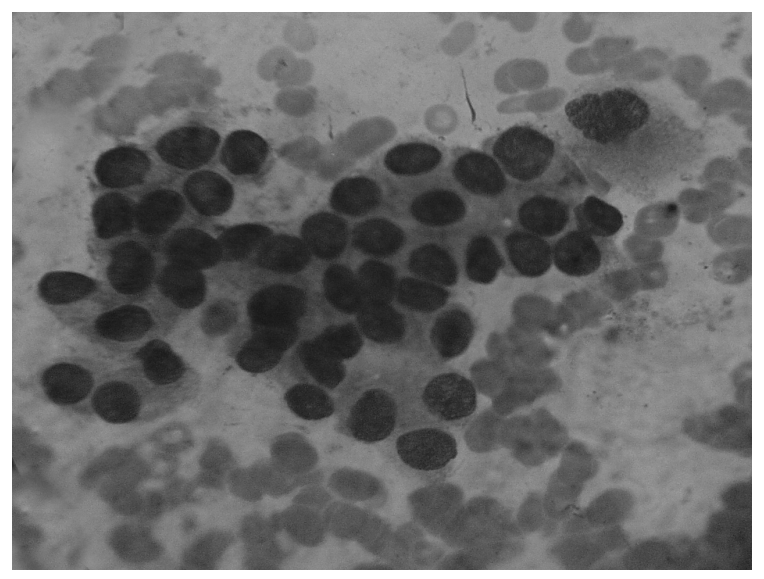

Figure 4. Cerebriform nucleus (May Grünwald Giemsa

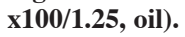

The statistical methods used included $\chi^{2}$ analysis and Fisher's exact test and KolmogorovSimirnov Test $(\alpha=0.05)$.

\section{RESULTS}

Age of the patients ranged from 19 to 66 years with median of 42 years, and $18 \%$ $(n=10)$ of the cases were male and $82 \%(n=46)$ of them were female. The cytological features, which were found to be statistically significant, are shown in Table 1.

The cytological findings, which were found to be statistically significant, in defining nodular hyperplasia, are absence of angulated $(n=28,68.3 \%)$ and cerebriform $(n=29,58 \%)$ nuclei, small nuclear size (nuclear size $<x 2$ of a red blood cell, $\mathrm{n}=25,78.1 \%$ ), the presence of diluted colloid $(n=22,73.3 \% ; p<0.05)$, mild monolayered sheet $(n=19,76 \% ; p<0.05)$ and presence of a few macrophages $(n=9,90 \%)$, absence of multilayered rosettes $(n=29,23.5 \%)$, absence of a nuclear grooves $(\mathrm{n}=25,65,8 \%)$ and nucleoli $(\mathrm{n}=21,77,8 \%)(\mathrm{p}<0.05)$ (Table 2, 3 and $4)$. The presence of a follicular cell ring, flame cells, Hurthle cells, hyperplastic papillae, hyaline stromal fragments and intact follicules did not appear to have any importance in cytological diagnosis of $\mathrm{NH}$.

Cerebriform nuclei $(n=6,100 \%)$ and angulated nuclei $(n=9,60 \%)(p<0.05)$ were the most important diagnostic cytological features for FVPC cases as well as the presence of INI $(n=4,66.7 \%)$ and nuclear grooves $(n=6,37.5 \%)$ $(\mathrm{p}<0.05)$ (Table 2 and 4). Cellularity, nuclear size, the presence of follicular cell rings, colloid, flame cells, Hurthle cells, hyperplastic papillae, hyaline stromal fragments, intact follicules, macrophages, monolayered sheets, multilayered rosettes and nucleoli were not found to be diagnostic for FVPC ( $p>0.05)$.

In FA cases, the only significant cytological feature was the nuclear size $(>\mathrm{x} 2$ of a red blood cell, $n=9,37.5 \%)(p<0.05)$ (Table 2). The presence of follicular cell ring, colloid, flame cells, Hurthle cells, hyperplastic papillae, hyaline stromal fragments, INI, intact follicules, macrophages, monolayered sheets, multilayered rosettes, nuclear grooves or nucleoli was not 
Table 1. Histopathological diagnosis according to criteria which were found statistically significant.

\begin{tabular}{lccccc}
\hline Criteria & FC & FVPC & FA & NH & Total \\
& $\mathbf{n}(\boldsymbol{\%})$ & $\mathbf{n}(\boldsymbol{\%})$ & $\mathbf{n}(\boldsymbol{\%})$ & $\mathbf{n}(\boldsymbol{\%})$ & $\mathbf{n}(\boldsymbol{\%})$ \\
\hline Colloid-dilue & 1 & 4 & 3 & 22 & 30 \\
& $(3,3)$ & $(13,3)$ & $(10,0)$ & $(73,3)$ & $(100)$ \\
Macrophage-mild & 0 & 1 & 0 & 9 & 10 \\
& $(0,0)$ & $(10,0)$ & $(0,0)$ & $(90,0)$ & $(100)$ \\
Multilayered rosette-absent & 4 & 6 & 12 & 29 & 51 \\
& $(7,8)$ & $(11,8)$ & $(23,5)$ & $(23,5)$ & $(100)$ \\
Monolayered sheet-mild & 3 & 3 & 0 & 19 & 25 \\
& $(12,0)$ & $(12,0)$ & $(0,0)$ & $(76,0)$ & $(100)$ \\
Intranuclear inclusion & 0 & 4 & 1 & 1 & 6 \\
INI)-mild & $(0,0)$ & $(66,7)$ & $(16,7)$ & $(16,7)$ & $(100)$ \\
Nuclear groove-absent & 3 & 1 & 9 & 25 & 38 \\
& $(7,9)$ & $(2,6)$ & $(23,7)$ & $(65,8)$ & $(100)$ \\
Nuclear groove-mild & 2 & 6 & 4 & 4 & 16 \\
& $(12,5)$ & $(37,5)$ & 25,0 & 25,0 & 100 \\
Angulated nucleus-absent & 3 & 0 & 10 & 28 & 41 \\
& 7,3 & 0,0 & 24,4 & 68,3 & $(100)$ \\
Angulated nucleus-mild & 2 & 9 & 3 & 1 & 15 \\
& $(13,3)$ & $(60,0)$ & $(20,0)$ & $(6,7)$ & $(100)$ \\
Cerebriform nucleus-absent & 5 & 3 & 13 & 29 & 50 \\
& $(10,0)$ & $(6,0)$ & $(26,0)$ & $(58,0)$ & $(100)$ \\
Cerebriform nucleus-mild & 0 & 6 & 0 & 0 & 6 \\
& $(0,0)$ & $(100,0)$ & $(0,0)$ & $(0,0)$ & $(100)$ \\
Nuclear size -<x2 & 0 & 3 & 4 & 25 & 32 \\
& $(0,0)$ & $(9,4)$ & $(12,5)$ & $(78,1)$ & $(100)$ \\
Nuclear size ->x2 & 5 & 6 & 9 & 4 & 24 \\
& $(20,8)$ & $(25,0)$ & $(37,5)$ & $(16,7)$ & $(100)$ \\
Nucleoli-absent & 2 & 2 & 2 & 21 & 27 \\
& $(7,4)$ & $(7,4)$ & $(7,4)$ & $(77,8)$ & $(100)$ \\
Total n (\%) & 5 & 9 & 13 & 29 & 56 \\
& $(8.8)$ & $(16.1)$ & $(23.2)$ & $(51.8)$ & $(100)$ \\
\hline & & & & & \\
\hline & & & & & \\
& & &
\end{tabular}

FC: Follicular carcinoma

FVPC: Follicular variant of papillary carcinoma

FA: Follicular adenoma

NH: Nodular hyperplasia

Table 2. Results of Fisher's Exact Test for follicular-patterned thyroid lesions.

\begin{tabular}{lcccc}
\hline & \multicolumn{4}{c}{ Fisher's Exact Test p value } \\
\cline { 2 - 5 } Criteria & FC & PCFV & FA & NH \\
\hline Cellularity & 1,000 & 1,000 & 0,510 & 0,579 \\
Nuclear size & 0,110 & 0,151 & $0,031^{*}$ & $0,000^{*}$ \\
Cerebriform nucleus & 1,000 & $0,000^{*}$ & 0,318 & $0,009^{*}$ \\
Angulated nucleus & 0,602 & $0,000^{*}$ & 1,000 & $0,000^{*}$ \\
\hline
\end{tabular}

$* p<0,05$

Table 3. Results of Kolmogorov-Simirnov Test for NH and FVPC.

\begin{tabular}{llcc}
\hline Criteria & & Z value & p value \\
\hline NH & Nuclear groove & 1,423 & $0,002^{*}$ \\
& Nucleoli & 1,877 & $0,035^{*}$ \\
& Multilayered roset & 1,858 & $0,002^{*}$ \\
& Macrofage & 1,390 & $0,042^{*}$ \\
FVPC & Nuclear groove & 1,858 & $0,002^{*}$ \\
& Intranuclear inclusion & 1,410 & $0,038^{*}$ \\
\hline
\end{tabular}

Table 4. Histopathological diagnosis and nodule size.

\begin{tabular}{lcccc}
\hline $\begin{array}{l}\text { Comparison of } \\
\text { Histopathological } \\
\text { Diagnosis }\end{array}$ & $\mathbf{n}$ & $\begin{array}{c}\text { Mean } \\
\text { Value }\end{array}$ & $\begin{array}{c}\text { Mann-Whitney } \\
\text { U value }\end{array}$ & p value \\
\hline FC & 5 & 10,00 & 5,000 & $0,027^{*}$ \\
FVPC & 9 & 5,13 & & \\
FC & 5 & 14,40 & 8,000 & $0,015^{*}$ \\
FA & 13 & 7,62 & & \\
FC & 5 & 29,10 & 14,500 & $0,004^{*}$ \\
NH & 29 & 15,50 & & \\
FVPC & 9 & 7,56 & 24,500 & $0,045^{*}$ \\
FA & 13 & 13,12 & & \\
FVPC & 9 & 13,06 & 68,500 & 0,078 \\
NH & 29 & 20,64 & & \\
FA & 13 & 23,81 & 158,500 & 0,409 \\
NH & 29 & 20,47 & & \\
\hline
\end{tabular}

$* p<0,05$

statistically significant $(\mathrm{p}>0.05)$.

In case of FC, we could not define any statistically significant cytological diagnostic criteria for, but nodule size, which is a clinical parameter, was found more significant than the other lesions.

\section{DISCUSSION}

Fine needle aspiration cytology of the thyroid has been a standard procedure in the preoperative examination of patients for many years. This procedure is recommended by most of the guidelines $(1,2,3,6,7,8)$. Fine needle aspiration should be the first test to be ordered in an euthyroid patient with a palpable thyroid nodule $(9,10)$. Most cytopathologists follow a "cytological classification" which is usually divided into 4 categories: inadequate cytology, benign lesion, suspicious lesion for malignancy, and malignant lesion. Sometimes "a doubtful (suspicious) lesion" or "follicular neoplasm favouring benign or malignant" can be added as a fifth category (8). Thyroid FNAC is indeterminate in $5-42 \%$ patients who later has established diagnoses of atypical, follicular lesion, follicular neoplasm, or suspicious for malignancy $(6,11)$. Indeterminate diagnoses can lead to repeat aspiration or surgical excision (12). One important limitation is its inability to differentiate certain percentage of follicular lesions $(6,12,13,14,15)$. 
Deshpande et al. have used the term follicular neoplasm in FNAC of the thyroid for hyperplastic nodules, follicular adenomas and follicular carcinomas due to difficulty in differentiating these three lesions by FNAC (16).

The accuracy rate of a definitely malignant diagnosis with thyroid FNAC has been shown to range between 90 and $100 \%$; however, only the up to $20 \%$ of the cases diagnosed as "follicular neoplasms" were reported as malignant on the examination of the surgical excision materials $(12,14)$. The goal of thyroid FNAC is to identify the nodules that require surgery and to decrease the number of unnecessary thyroidectomies for patients with benign disease $(15,17)$.

Among 4080 FNAC samples, 225 $(5.51 \%)$ of them were diagnosed as "suspicious cytology for follicular patterned lesions". Fifty six of two hundred and twenty five cases $(24.88 \%)$ underwent surgical excision. Histopathological diagnoses of these 56 cases were malignant in 14 (25\%) and benign in 42 (75\%) cases. Among the benign lesions, 29 (1.8\%) were nodular hyperplasia, and $13(23.2 \%)$ were follicular adenomas. These findings were similar to those of Baloch et al. where 9 nodules (69\%) were benign, and 4 nodules $(31 \%)$ were malignant (18). Greaves et al. reported an excision rate of $41 \%$, with 67 benign lesions $(70 \%)$ and 29 malignancies (30\%) (6).

Baloch et al. reported that nodules of 3 $\mathrm{cm}$ or greater were commonly associated with malignancy (12). In our study, the size of the FC nodules was greater than all other follicularpatterned lesions, but the size of the nodules in FAs was greater than the nodules of FVPC $(\mathrm{FC}>\mathrm{FA}>\mathrm{FVPC}>\mathrm{NH})$.

We found that that the most significant distinguishing features of nodular hyperplasia different from other follicular-patterned lesions were diluted colloid $(73,3 \%)$, monolayered sheets $(76.0 \%)$, smaller nuclear size $(<x 2)(78.0 \%)$, the presence of a few macrophages $(90.0 \%)$ and absence of nucleoli $(77.8 \%)(\mathrm{p}<0.05)$.
For the (cyto)pathologist, diagnosis of a benign lesion is based on the following criteria (that may be applied to a solitary nodule as well as a multinodular thyroid gland): an average number of cells, abundant colloid, the lack of follicular architecture or a very discrete microfollicular architecture, the absence of anisokaryosis and marked hyperchromatism, the lack of nucleolar hypertrophy, and sometimes a few fibroblasts and a variable number of histiocytes (8).

Hag et al. reported that $\mathrm{NH}$ was histologically characterized by the presence of hyperplastic papillae. Hyperplastic papillae were easily recognised in cell blocks and less readily in smears (1). But Kung et al. reported their presence in only $8 \%$ of the smears from the cases of NH (19). In our materials, hyperplastic papillae were detected in $66,7 \%$ of smears of $\mathrm{NH}$, but this was not statistically significant $(p>0,05)$. The occurrence rate of Hp in FVPC was found out to be $25 \%$. This value was similar to that found by Hag et al. They reported the incidences of hyperplastic papillae and colloid in FVPC as $25 \%$ and $75 \%$, respectively (1). But Hp should not be accepted as a definitive sign of benignity. Overlapping nature of these features made the differentiation of FVPC from NH rather difficult. Other features frequently encountered in $\mathrm{NH}$ were follicular cell rings, flame cells, Hurthle cells, hyaline stromal fragments, intact follicules and less frequently INI, NG and angulated nuclei (Table 1).

The FVPC is the most common cause for false-negative FNA results. The presence of abundant colloid, monolayer sheets, and paucity of nuclear features of papillary carcinoma caused diagnostic difficulties (11).

Cytological findings such as colloid, multilayered rosettes, follicular cell rings, monolayered sheets, hyperplastic papillae, hyaline stromal fragments, nuclear groove- even present focally- are important clues to identify FVPC (11). The diagnosis of FVPC is solely dependent on the nuclear features (oval, enlarged, overlap- 
ped nuclei with optically clear or ground-glass appearance and frequent grooves and pseudoinclusions) (20). The characteristics of optically clear nuclei of papillary carcinoma may be caused by the alteration of chromatin associated with RET/PTC oncogene, enhanced by formalin fixation artefact and are not seen in cytological specimens, except when processed with Ultrafast Pap stain $(20,21)$.

In our study, the presence of cerebriform nuclei, angulated nuclei, nuclear grooves, intranuclear inclusions was statistically highly significant $(p<0,05)$ in differentiation of papillary carcinoma folliculary variant from follicular neoplasm. Additionally, we found out that the presence of cerebriform cells in FVPC (100 $\%$ ) is very important, as they have been described a little in this neoplasm previously in the literature $(22,23)$.

$\mathrm{Wu}$ et al. reported that the cytological diagnosis of FVPC could be difficult because of the paucity of nuclear changes of papillary carcinoma and overlapping features of both benign and malignant follicular lesions (20). In some cases, cytological interpretation of FVPC may also be difficult owing to the paucity of nuclear features of papillary carcinoma, and can be mistaken as hyperplastic nodules. Baloch et al. diagnosed such lesions as suggestive of papillary carcinoma and recommended intraoperative frozen section and touch preparation for definitive diagnosis (5).

In FNA of FVPC, the most consistent low-power architectural finding is the presence of flat syncytial sheets. Flat syncytial sheets in FVPC often branch with nuclear crowding and are different from flat sheets of colloid nodule, which usually form a honeycomb pattern (20). In our study, monolayered sheets were present in $12 \%$ of FVPC.

In our study, the only significant cytological feature was the nuclear size $(>x 2$ of a red blood cell) for FA. Other cytological criteria were not statistically significant. El Hag et al. reported that FA showed none of the aforemen- tioned features. They were always moderately cellular, usually devoid of colloid and demonstrated rings and round to ovoid crowded clusters of follicular cells (1). Similar results were also reported by Das et al. (12).

The assessment of detailed cytological findings of follicular-patterned thyroid lesions was helpful in differential diagnosis between follicular variant of papillary carcinoma and nodular hyperplasia. We think that the presence of cerebriform nucleus in FVPC is very important. Differentiation among various follicularpatterned lesions of thyroid will decrease the number of unnecessary surgeries. Additionally, cytological findings are not sufficient enough to distinguish follicular adenoma from follicular carcinoma. Therefore, (cyto)pathologists should continue to indicate these lesions as "follicular neoplasms" in fine-needle aspiration cytology reports of the thyroid.

\section{REFERENCES}

1. El Hag A, Kollur SM. Benign follicular thyroid lesions versus follicular variant of papillary carcinoma: differentiation by architectural pattern. Cytopathology 2004;15:200-205.

2. Goldstein RE, Netterville JL, Burkey B, Johnson JE. Implications of follicular neoplasms, atypia and lesions suspicious for malignancy diagnosed by fine-needle aspiration of thyroid nodules. Ann Surg 2002;225:656664.

3. Ersöz C, Firat P, Uguz A, Mocan Kuzey G. Fine-needle aspiration cytology of solitary thyroid nodules. Cancer (Cancer Cytopathol) 2004;102:302-307.

4. Zacks JF, Morenas AdI, Beazley RM, O'brien MJ. Fine-needle aspiration cytology diagnosis of colloid nodule versus follicular variant of papillary carcinoma of the thyroid. Diagn Cytopathol 1998;18:87-90.

5. Yang GCH, Liebeskind D, Messina AV. Should cytopathologists stop reporting follicular neoplasms on fine-needle aspiration of the thyroid? Cancer (Cancer Cytopathol) 2003;99:69-74.

6. Baloch ZW, Livolsy VA. Follicular patterned lesions of the thyroid. Am J Clin Pathol 2002;117:143-150.

7. Greaves TS, Olvera M, Florentine BD, Raza AS, Cobb CJ, Tsao-Wei DD et al.. Follicular lesions of thyroid. Cancer (Cancer Cytopathol) 2000;90:335-341.

8. Logani S, Gupta P, LiVolsi VA, Mandel S, Baloch ZW. Thyroid nodules with FNA cytology suspicious for follicular variant of papillary thyroid carcinoma: follow-up and management. Diagn Cytopathol 2000;23:380-385.

9. Baloch ZW, LiVolsi VA. Our approach to follicular- 
patterned lesions of the thyroid. J Clin Pathol 2007;60:244-250.

10. Lerma E, Mora J, Thyroid Study Group. Telomerase activity in "suspicious" thyroid cytology. Cancer (Cancer Cytopathol) 2005;105:492-7.

11. Priollet BC, Thienpont FL. Aspiration cytology in diagnosis of thyroid lesions. Cytopathology 2005;16:6567.

12. Welker MJ, Orlov D. Thyroid nodules. Am Fam Physician 2003;67:559-66,573-574.

13. Baloch Z, Latfield LJ. Quest for a uniform cytodiagnostic approach to thyroid aspirates: a consensus proposal. Diagn Cytopathol 2005;34:85-86.

14. Deveci MS, Deveci G, LiVolsi VA, Baloch ZW. Fineneedle aspiration of follicular lesions of the thyroid: diagnosis and follow-up. Cytojournal 2006;3:9.

15. Raber W, Kaserer K, Niederle B, Vierhapper H. Risk factors for malignancy of thyroid nodules initially identified as follicular neoplasia by fine-needle aspiration: results of a prospective study of one hundred twenty patients. Thyroid 2000;10:709-712.

16. Wu HHJ, Jones JN, Osman J. Fine-needle aspiration cytology of the thyroid: ten years experience in a community teaching hospital. Diagn Cytopathol 2005;34:93100.

17. Baloch ZW, Fleisher S, Livolsy VA, Gupta PK. Diagnosis of "follicular neoplasm": a grey zone in thyroid fine needle aspiration cytology. Diagn Cytopathol 2002;26:41-44.

18. Das DK, Khanna CM, Tripathi RP, Pant CS, Mandal AK, Chandra S, et al. Solitary nodular goitre: review of cytomorphologic features in 441 cases. Acta Cytol 1999; 43:563-574.

19. Berner A, Sigstad, Pradhan M, Grøholt KK, Davidson B. Fine needle aspiration cytology of the thyroid gland: comparative analysis of experience at three hospital. Diagn Cytopathol 2006;34:97-100.

20. Deshpande V, Kapila K, Sai KS, Verma K. Follicular neoplasms of the thyroid: decision tree approach using morphologic and morphometric parameters. Acta Cytol 1997;41:369-376.
21. Sanchez N, Selvaggi SM. Utility of cell blocks in the diagnosis of thyroid aspirates. Diagn Cytopathol 2005;34:89-92.

22. Baloch ZW, Sack MJ, Yu GH, Livolsi VA, Gupta PK. Fine-needle aspiration of thyroid: an institutional experience. Thyroid 1998;8:565-569.

23. Kung ITM, Yuen RWS. Fine needle aspiration of thyroid distinction between colloid nodules and follicular neoplasms using cell blocks and 21 - gauge needle. Acta Cytol 1989;33:53-60.

24. Gallagher J, Oertel YC, Oertel JE. Follicular variant of papillary carcinoma of the thyroid: fine-needle aspirates with histologic correlation. Diagn Cytopathol 1997; 16:207-213.

25. Powari M, Dey P, Saikia UN. Fine needle aspiration cytology of follicular variant of papillary carcinoma of thyroid. Cytopathology 2003;14:212-215.

26. Wu HHJ, Jones JN, Grzybicki DM, Elsheikh TM. Sensitive cytologic criteria for the identification of follicular variant of papillary thyroid carcinoma in fine-needle aspiration biopsy. Diagn Cytopathol 2003;29:262-266.

27. Delellis RA, Lloyd RV, Heitz PU, Eng C. Papillary Carcinoma. In: LiVolsi VA, Albores-Saavedra J, Asa SL et al. editors. Pathology \& Genetics Tumours of Endocrine Organs, World Health Organization . IARC Press, 2004, p:57-66.

28. Yang GC, Greenebaum E. Clear nuclei of papillary thyroid carcinoma conspicuous in fine-needle aspiration and intraoperative smears processed by Ultrafast papanicalou stain. Mod Pathol 1997;10:552-555.

29. Mallik MK, Das DK, Mallik AA. Dark and pale cerebriform nuclei in FNA smears of usual papillary thyroid carcinoma and its variants. Diagn Cytopathol 2004;30:187-192.

30. Bell CD, CoirenC, Treger T. The dark nucleus and disruption of follicular architecture: possible new histological aids for the diagnosis of the follicular variant of papillary carcinoma of the thyroid. Histopathology 2001;39:33-42. 